\title{
Differentiation by Degrees: System Design and the Changing Undergraduate Environment in Canada
}

\author{
Dave Marshall \\ Mount Royal College
}

\begin{abstract}
There has been a significant growth in the number and types of degrees offered by a wider variety of Canadian post-secondary institutions. This expansion of degree access is the legitimate response to various forces, both social and post secondary. However, as a result, there has been some confusion regarding the meaning and value of the new degrees offered by the increasing variety of institutions. Several provinces are now recognizing this confusion through initiatives to "redesign" their provincial post-secondary systems and this may ultimately reduce the diversity and the confusion. However, this paper examines the forces that have led to this proliferation of degrees and institutions and discusses the problems and controversies that are brewing regarding the recognition of these new degrees for further study and the proposals for system redesign. In particular, it is proposed that an examination of both the substance of various degrees and the nature of the institution offering the credential can provide a context for understanding the meaning of various degrees. Recommendations to help resolve the growing concerns in this area are provided for nonuniversity degree-granting institutions, Canadian universities, and for provincial governments developing degree granting policies as part of system redesign initiatives.
\end{abstract}

\section{RÉSUMÉ}

Les institutions d'enseignement postsecondaires canadiennes, un groupe de plus en plus diversifié, offre une variété et un nombre croissants de diplômes. Cet accroissement constitue une réponse légitime à diverses forces tant sociales que spécifiques au contexte 
de l'enseignement postsecondaire. Toutefois, il en résulte une certaine confusion quant à au sens et à la valeur des différents diplômes offerts et des institutions d'enseignement. Certaines provinces réagissent à ce phénomène en prenant l'initiative de réformer leur système d'enseignement postsecondaire, ce qui à terme pourrait réduire la diversité et la confusion. Cet article examine les forces ayant mené à la prolifération des diplômes et des institutions, examinant les problèmes et les controverses ayant trait à la reconnaissance de ces nouveaux diplômes et aux réformes proposées. En particulier, l'article suggère qu'un nouvel examen tant du contenu des programmes que de la nature des institutions offre un contexte permettant de mieux comprendre le sens des divers diplômes. Des recommandations visant à répondre aux inquiétudes croissantes en cette matière sont proposées à l'attention des institutions non-universitaires offrant des diplômes, des universités canadiennes et des gouvernement provinciaux.

A noticeable change has occurred in the delivery of undergraduate degrees in Canada over the past 15 years. The Canadian undergraduate market has gone from consisting primarily of public university-delivered credentials to an environment with a variety of new undergraduate degrees delivered by myriad of institutions ${ }^{1}$. Although most degree students are still enrolled at traditional Canadian public universities, the choices have been growing at a rapid pace.

Internationally, this is not a new phenomenon, and there have been efforts to describe and define the increasing differentiation of post secondary institutions (Meek, Goedegebuure, Kivinen \& Rinne, 1996). In Canada, Jones (1996) described the emerging diversity of Canadian post secondary education in the early 1990s. For Statistics Canada purposes, Orton (2003) suggested a new grouping of Canadian post secondary institutions that recognized newer degree granting institutions. Orton was probably the first to suggest a typology that is at least partially based on the delivery of baccalaureate credentials rather than simply "title." This diversification of institutions delivering undergraduate credentials has led to studies of the effect of these reforms on access (Dennison \& Schuetze, 2004), of the effects of the examination of Canada's processes for accrediting university institutions (Marshall, 2004a), of the role of colleges in granting degrees (Skolnik, 2004), of the effects of such degree proliferation on degree inflation (Marshall, 2004b), along with a study of the effect of membership in the Association of Universities and Colleges of Canada (AUCC) on student acceptance for further study at Canadian universities (Marshall, 2006).

However, this expansion of degree types and degree-granting institutions continues to generate confusion (particularly among parents and students) about the meaning and value of new undergraduate degrees delivered by nonuniversity institutions ${ }^{2}$ (Skolnik, 2006). More specifically, as the graduates of these degrees enter the workforce and seek further credentials, confusion is arising regarding the preparation of these graduates for further study. ${ }^{3}$ This paper examines the issue of degree and institutional differentiation in Canada and 
the implications of this differentiation for both the degree-granting institutions and undergraduate degree recipients.

\section{The Forces at Play: How Did We Get Here?}

All degrees offered in Canada require provincial government approval. Consequently, political motivation, for whatever the reason, has been the most important factor in the approval of alternative degree-granting institutions and degrees. Typical of most political action, the response is based on a combination of fact and assumption.

The following are some of the forces and assumptions that have led to the proliferation of government approval of alternative degree sources.

\section{Creeping Credentialism and the Value of the Degree}

The degree has gradually become the professional and employment credential of choice. More and more professional groups, from accountants to health professions, have changed certification requirements to require a bachelor's degree for certification or entry into the profession. In some cases, this has had a relatively minor effect. But, in others, (e.g., teacher education several decades ago and nursing today) and in the aggregate, these changes have caused a significant increase in demand for the degree credential.

\section{Perceived Elitism of the Gatekeepers}

In Canada, the gatekeepers of the degree experience have been the publicly funded universities. Although participation rates at universities have significantly increased over the past 35 years, there is a lingering perception that the traditional university monopoly on the degree experience has been slow to change and has artificially limited access; therefore, economic progress of our country and its citizens has been limited. Although governments control the number of places that are funded, it is universities that take the brunt of the criticisms regarding restricted access to degree programs.

\section{Satisfaction: The Undergraduate Crisis and the Post-secondary Gap}

Perhaps as early as the 1980s, (but most assuredly by the 1990s), there was growing public discontent with aspects of the Canadian post-secondary system. At the college level, many parents, students, and employers were concerned that some of traditional college credentials were no longer sufficient for entry to the workplace. The shift in requirements for a Certified General Accountant (CGA) designation from a college diploma to a university degree is an example of one challenge facing the college credential. Efforts to increase transfer arrangements to universities, a renewed focus on "learner centered" organizations, and the introduction of applied degrees in several provinces, are examples of an evolving college system responding to these concerns (Skolnik, 2004). 
The discontent, however, was more obvious at the university level. At one end of the university role, the intense lobby to enhance the research capability (as a key to Canadian competitiveness in a new "knowledge" economy) has resulted in increased investment in the research agenda at all Canadian universities (Canada, 2004). This has motivated even the smallest Canadian universities to turn to the traditional university research and scholarly mission. At the other end of the university role, there continues to be growing discontent with the instructional and/or undergraduate environment. Stuart Smith's 1991 federal Commission on Post Secondary Education was one of the first to criticize Canadian universities for their disregard for both teaching and the undergraduate student (Smith, 1991). Pocklington and Tupper's (2002) book No Place to Learn repeated much of Smith's observations on the state of undergraduate education in Canadian universities.

\section{Demography Demand}

In addition to the increasing participation rate at universities, the size of the 18-29 age cohort is projected to increase over the next decade in some parts of the country (and decline in others), creating a significant increase in demand for university degrees in some parts of the country. This demand will be most evident in places like Alberta where the youth participation rate in university education is the lowest in the country, in all provinces where first nations youth are underrepresented in university-level education, and in metro Ontario where the youth population is growing.

\section{Mid-Career Education and Lifelong Learning}

The mid-career, mature learner has been largely ignored by the mainstream university (except the executive MBA) but embraced by alternative degree-granting institutions. Royal Roads University, University of Phoenix, and Athabasca University are places that respond to mid-career needs and provide delivery models outside of the eight-month, residential traditional university format.

\section{Degrees and Institutions with Special Meaning}

There are those who believe that their special degree interest or learning need cannot be met by the traditional university model. Religiously affiliated institutions provide a learning environment and perspective that many in the faith based sector believe is not possible in the publicly funded university. In some provinces, applied degrees are intended to add an academic component to a previously vocational or technical credential. The University of Ontario Institute of Technology has stated that its degrees will be workplace oriented, building the rationale for their institution on the assumption that the existing degree model somehow falls short in this regard. The new Thompson Rivers University in British Columbia and the proposal by Mount Royal in Alberta to change from a college to a university are initiatives to establish "instruction- 
ally" focused yet scholarly-based universities. Canada's four art colleges (two are now called universities) have provided a unique post secondary environment. And finally, there is the growth, largely in Alberta and British Columbia, of "private" universities. Alberta has been something of a "Mecca" for the faith based, not for profit university colleges, while British Columbia has chartered several small private secular "universities" over the past decade.

\section{A Government Agenda}

Governments have seen the option of degrees delivered by non-university institutions as a way to provide increased access to bachelor's degrees with more flexibility of delivery and generally, without all of the components of the traditional university environment.

\section{The College Baccalaureate Movement}

There has been a movement by some sectors of the Canadian (and U.S.) community college community to promote the delivery of foundational baccalaureate degrees in a college environment (Skolnik, 2004).

There may be other permutations of these forces that have led to enhanced degree-granting opportunities in Canada, but in general, the result has been the willingness in many Canadian provinces to crack the university monopoly on the undergraduate degree-granting experience through the approval of new degrees and even proposals for complete system redesign. The result is a proliferation over the past two decades of new "degree" experiences that are delivered by private for-profit, private not-for-profit, non-secular, virtual and non-university institutions. The "credentials" are coming in an array of degree labels from associate degrees to applied degrees to professional degrees and to graduate and executive degrees that are clearly differentiated from the degree label and degree experience previously offered only in the mainstream Canadian university. It is currently estimated that there are approximately 75 degrees of various types and nomenclature delivered in Canada by over 40 non-university (non-AUCC) institutions. British Columbia alone reports over 3,400 graduates from degree programs at university colleges, colleges and institutes. (Millar, 2007).

\section{The Problem and the Controversy}

The meaning, purpose, value and, ultimately, the recognition of all of these different types of degrees are a growing concern in Canada. Currently, the discussion is similar to the debates that have occurred about the recognition of college-level credits at the university level. These discussions started with colleges demanding one-to-one credit recognition for college course transfers to universities (Ontario, 1993) and universities either ignoring the issue or stating that current college credit transfer was sufficient. Alberta and British Columbia responded to this challenge by establishing both credit transfer agencies and ultimately extensive credit transfer guides. ${ }^{4}$ Although still under discussion in 
some jurisdictions, the credit transfer issue has been addressed in several ways. Colleges have agreed that credit transfer should not be automatic and there are many variables that affect the transferability of credits (e.g., affınity, purpose, curriculum). Universities have agreed that relevant college level learning should be recognized in some way at all levels of the post-secondary system. Some university organizations have begun to develop policies regarding the acceptability of different types of degrees (Marshall-Patterson Memorandum, 2004). However, the debate about the acceptance of full degrees is relatively new since it is only recently that the graduates from these institutions have hit the employment or further study market. The substance of the previous debates about credit transfer is being repeated in the discussion about degree recognition.

There are, however, some differences between the issues of credit transfer and the issue of full recognition of degrees. The proliferation of new degrees from non-university institutions has left many universities uncertain that these degrees provide the outcomes necessary for further study. This uncertainty leads to many questions such as the following:

- Does an applied-type degree have a curriculum that allows for the depth and breadth of study traditionally associated with the baccalaureate label?

- Could an institution grant one or two credible baccalaureates that achieve the accepted degree outcomes when these degree enrolments represent a small or a minority percent of the institution's enrolment and, consequently, are delivered in a "non university" environment?

- Can a degree offered in an environment where academic freedom is not ensured represent the breadth of knowledge expected from a baccalaureate?

- What role does research and scholarship play in the degree environment and meaning and what level of scholarship is necessary in a degree granting institution?

- Is bicameral governance necessary to ensure academic autonomy and continual quality assurance in a degree granting environment?

Although the problem derives from the proliferation of the new types of degrees, the challenge comes from the ongoing disagreement between the university and non-university sectors about the implications for future study of both the substance of the undergraduate curriculum and the institutional environment.

\section{The Recognition of Bachelor's Degrees}

Even before the current expansion of degree and institution types, there was differentiation of degree and institutional type within the Canadian university system. At the undergraduate level, there have always been three-year general degrees, four-year general degrees, honors degrees, professional degrees, and even applied degrees (some engineering degrees have been called Bachelor of Applied Science). There has also always been a range of public institutional types in Canada, from the smaller undergraduate-focused univer- 
sities (and some affiliated colleges) to special purpose institutions such as the colleges of art and design, to the large urban research and graduate-focused universities. Yet, there was no mistaking that these were all university-level institutions and there was very little questioning of the value or substance of the degrees delivered. Although there never was any guarantee that a student would be admitted to a graduate or professional school, it could at least be guaranteed that they would be eligible for admission. ${ }^{5}$ This guarantee was based upon assumptions about both the institution offering the degree and the substance of the degree itself.

The substance of the degree. Considerable worldwide progress has been made over the past decade in describing the meaning of the bachelor's degree and the substance of the various degree labels. For example, the Council for Higher Education Accreditation Board in the United States provides the following distinction between the degree and other credentials.

Other kinds of credentials can, in their own particular contexts, be worthy and valuable. The degree is distinguishable by its requirement, in general, that a greater number of credits, representing a broader scope of study, be accumulated; by its general education expectations; and by its emphasis on the life of the mind. While some of the benefits of the degree can be obtained by other forms of credentialing, the degree uniquely represents the capacities and skills identified above. (Council for Higher Education Accreditation, 2001)

In Canada, groups such as the Campus Alberta Quality Council (CAQC), the Ontario Postsecondary Education Quality Assessment Board (PEQAB), the British Columbia Degree Quality Assessment Board (BCDQAB), and the Council of Ontario Universities (COU) have developed clear outcomes that should be expected for each of the different degree labels. In addition, the Council of Ministers of Education, Canada (CMEC) proposed a pan-Canadian protocol on degree outcomes that has now been adopted by all Canadian provinces. These degree outcome exercises in Canada and elsewhere play a critical part in resolving the growing confusion about the meaning of new degrees.

However, the important issue for this discussion is that it has always been assumed that these outcomes (breadth and generic skills) have been achieved by any baccalaureate holder and, consequently, graduate or professional schools have built programs based upon rather than repeating these knowledge areas. Thus, a post-degree B.Ed. or a LLB program is built upon the assumption that the degree holder has the requisite subject matter background and a breadth of knowledge and literacy as well. A graduate school assumes that the degree holder is sufficiently grounded in the basics of scholarly work and research before starting the graduate curriculum. Consequently, the substance of the degree forms a major part of the basis for any future study. ${ }^{6}$

The nature of the institution. One of the significant challenges for the various degree outcome exercises is to determine how outcomes would be measured 
and how to achieve "quality assurance" or assurance that the delivering institution is able to deliver these outcomes (Randall, 2008). Simply claiming the outcomes for graduates may not be enough. Short of requiring some kind of national standard exam for all degree holders, the answer to this issue has traditionally been the assumption of a link between institutional environment and quality assurance.

In Canada, the university-level degree environment is defined by the various proprovincial quality assessment councils such as CAQC in Albert, but it is also defined by membership in the Association of Universities and Colleges of Canada (AUCC). The assessment for membership in AUCC is primarily an "institutional" assessment, examining the institution for the requirements necessary to deliver the degree outcomes expected of a bachelor's or higher degree (CMEC, 2007). These internationally-accepted characteristics of a university-level institution include the following: the legislated authority to offer university-level degrees, the appropriate qualifications of faculty, the support for scholarly work for faculty and students, and the appropriate educational (library and labs) facilities. AUCC also insists that a university-level institution in Canada have clear academic freedom policies, that the majority of the students in the institution be enrolled in programs leading to university credentials, and have a process whereby "authority vested in academic staff for decisions affecting academic programs including admissions, content, graduation requirements/standards, and related policies and procedures [is] through membership on an elected academic senate or other appropriate elected body representative of academic staff" (AUCC, 2004).

Degree recognition processes are based upon the principle that a university-level environment is necessary in order to ensure the graduate outcomes described by the various quality assessment bodies. Although the AUCC maintains that it was never meant to be an "accrediting" body, and while provincial councils such as CAQC are already ensuring degree level environments, today, AUCC membership is often used as a convenient proxy in Canada for the affirmation of "university level" particularly where no other institutional quality assessment process is in place.

\section{The Controversies}

In general, it is clear that degrees are differentiated by their label. A B.A. is different from a B.Sc. and a B.Sc. is different from an applied degree. Less common in Canada is the "typology" of different degrees where the degree is defined by the delivering institution. For example, the United States accreditation system accredits institutions by "type" ${ }^{8}$ and this classification implies a certain meaning and value to the degrees that the institution offers. These different meanings and values are reflected in the degree outcome exercises mentioned earlier and by and large, these assumptions generate little controversy.

However, most controversial is the notion that the nature of the institution will affect how both employers and other institutions will view the degree. 
Since AUCC was never established as an "accreditation" agency, it is often said that it is inappropriate to use AUCC as a filter for degrees, especially those already approved by a provincial government. As discussed above, the AUCC membership requirements simply reflect the commonly-held criteria defining a university-level institution, so the debate and controversy would be better focused upon the criteria used to define a "university level" environment rather than on the use of AUCC membership for degree recognition. Recent proposals for system redesign are attempting to address these challenges associated with degree and institution recognition.

\section{System Redesign and the Baccalaureate Institution}

As little as 25 years ago, the typical Canadian post-secondary spectrum consisted primarily of two ends with little in the middle. At one end, there was the traditional university with a combined research and teaching mandate and at the other end, was the traditional technical, career or community college with a focused teaching role. Despite the fact that both British Columbia and Alberta viewed the college and university system as more of a continuum than other provinces, and despite some other inter-provincial differences in approaches taken to the role of colleges and the development of new universities, the common public perception was of a distinct two sector post-secondary education system in Canada. Either you are one... or the other. However, as mentioned earlier in this paper, perhaps as early as the 1980s (but most assuredly by the 1990s), there was growing public discontent with aspects of the Canadian postsecondary system.

Apart from the challenges of access, this discontent with both the college and the university sectors stemmed from the growing awareness that the traditional role or values of either sector could not meet the needs of a growing number of students and employers who were looking for a new kind of "undergraduate" education. In simplest terms, they were looking for something that combined the best of the college model with the best of the university model. The unfilled "gap" appeared to be a post-secondary education that combined the college approach which focused upon instruction, community and industry response, open access, use of advisory groups, and work experience with the university scholarly environment and collegial governance.

Although there have been attempts across the country over the past two decades to blend the university and college missions, finding the right mix has not been easy. At the college level, initiatives include the development of applied degrees in British Columbia, Alberta, and Ontario, as well as the introduction of foundational degrees at two Alberta colleges (Mount Royal and Grant MacEwan).

At the university level, these initiatives would include the establishment of new, unique universities such as Ryerson University, Thompson Rivers University, and the University of Ontario Institute of Technology (UOIT). And the "hybrid" university colleges ${ }^{9}$ established in British Columbia from 1989 to 1995 represent initiatives to address the idea of combined missions (Marshall 2004a). 
There is even an international group forming to share international efforts to establish "New Generation Universities" (International Association of New Generation Universities, 2007).

These diverse initiatives at both the university and college level are at various stages of implementation and assessment, but all speak to one issue: helping to address access challenges by the filling of the emerging and growing "gap" between the traditional university model and the traditional college/institute model. There are no longer two clearly-defined sectors. Instead, there is a spectrum of post-secondary institutions emerging to meet the growing spectrum of student and employer needs.

Several provinces (Ontario, British Columbia, New Brunswick and Alberta) have recently released commissioned or ministry reports proposing new system models for post-secondary education that better reflect this spectrum. Although these reports are at various stages of acceptance/implementation (or rejection), a summary of some of the salient parts of these various reports for the purposes of this paper is presented in Table 1.

The various reports cover many aspects of post-secondary education in their provinces, but for the purposes of this paper, the most notable common recommendation in all reports is that bachelor's degree granting be limited to the universities, regional universities, selected polytechnics, or specialized baccalaureate institutions. For at least two provinces, this represents a reversal of previous policy that allowed all colleges to offer baccalaureates. Although the extent to which the various provinces will adopt the recommendations in these reports remains to be seen, this may represent, at least in part, a response to the concerns about the recognition of non-university degrees. The recognition of "baccalaureate" universities/institutions is perhaps a compromise to the option of a full return to a traditional university monopoly on baccalaureates.

Although there are some major differences in terminology and philosophy among the various reports, there appears to be surprising consistency in the identification of new categories of undergraduate institutions that would deliver baccalaureates. British Columbia would call them regional universities (five were proposed and have now been announced); Alberta proposed a category called "Baccalaureate and Applied Studies Institution" (Mount Royal and Grant MacEwan) as well as a polytechnic category (including SAIT and NAIT). Both the B.C. report and the Alberta reports have been largely implemented as of the end of 2008. However, although the New Brunswick report suggested some colleges and universities be joined and be called "polytechnics," this report has by and large been replaced with a subsequent government report and the notion of polytechnics for New Brunswick rejected. But regardless of the state of the various provincial studies and reports, it is clear that in order to avoid significant consumer confusion both nationally and internationally, the provinces should work to develop some common nomenclature for these institutions. However, the various reports have been consistent in identifying the need for baccalaureate-focused institutions that are instructionally-focused and scholarly-informed 
Table 1. Provincial Post secondary Commissions in Canada

\begin{tabular}{|c|c|c|c|c|}
\hline & $\begin{array}{l}\text { Ontario: } \\
\text { Rae Report } \\
\text { (Rae, 2005) }\end{array}$ & $\begin{array}{l}\text { British Columbia: } \\
\text { Campus 2020 } \\
\text { (Plant, 2007) }\end{array}$ & $\begin{array}{l}\text { New Brunswick: } \\
\text { Advantage New } \\
\text { Brunswick } \\
\text { (New Brunswick, } \\
\text { 2007) }\end{array}$ & $\begin{array}{l}\text { Alberta: Roles \& } \\
\text { Mandates Policy } \\
\text { Framework } \\
\text { (Alberta, 2007) }\end{array}$ \\
\hline Process & $\begin{array}{l}\text { Commissioned } \\
\text { consultative } \\
\text { process }\end{array}$ & $\begin{array}{l}\text { Commissioned } \\
\text { consultative } \\
\text { process }\end{array}$ & $\begin{array}{l}\text { Commissioned } \\
\text { consultative } \\
\text { process }\end{array}$ & Ministry document \\
\hline Principles & $\begin{array}{l}\text { Accessible, } \\
\text { affordable, ac- } \\
\text { countable, } \\
\text { global, quality, } \\
\text { collaborative }\end{array}$ & $\begin{array}{l}\text { Accessible, afford- } \\
\text { able, accountable, } \\
\text { global, quality, } \\
\text { collaborative }\end{array}$ & $\begin{array}{l}\text { Accessible, } \\
\text { affordable, ac- } \\
\text { countable, global, } \\
\text { quality, collab- } \\
\text { orative }\end{array}$ & $\begin{array}{l}\text { Accessible, afford- } \\
\text { able, accountable, } \\
\text { global, collaborative }\end{array}$ \\
\hline $\begin{array}{l}\text { System } \\
\text { Organization } \\
\text { (public only) }\end{array}$ & Bi-sectored & $\begin{array}{l}\text { Tri sectored: re- } \\
\text { search universities, } \\
\text { regional universi- } \\
\text { ties, colleges }\end{array}$ & $\begin{array}{l}\text { Tri sectored: } \\
\text { universities, } \\
\text { polytechnics, } \\
\text { college(s) }\end{array}$ & $\begin{array}{l}\text { Five-sectored: } \\
\text { comprehensive } \\
\text { research institutions, } \\
\text { baccalaureate institu- } \\
\text { tions, polytechnics, } \\
\text { comprehensive com- } \\
\text { munity institutions, } \\
\text { specialized institu- } \\
\text { tions }\end{array}$ \\
\hline $\begin{array}{l}\text { Baccalaureate } \\
\text { (non applied) } \\
\text { Degree Grant- } \\
\text { ing }\end{array}$ & Universities only & $\begin{array}{l}\text { Research and re- } \\
\text { gional universities }\end{array}$ & $\begin{array}{l}\text { Universities and } \\
\text { polytechnics }\end{array}$ & $\begin{array}{l}\text { Comprehensive } \\
\text { Research, Baccalau- } \\
\text { reate and Applied } \\
\text { Institutions, and } \\
\text { Polytechnics. }\end{array}$ \\
\hline $\begin{array}{l}\text { Research/ } \\
\text { Scholarship }\end{array}$ & $\begin{array}{l}\text { Colleges limited } \\
\text { to applied re- } \\
\text { search }\end{array}$ & $\begin{array}{l}\text { Regional universi- } \\
\text { ties are "instruc- } \\
\text { tionally" focused }\end{array}$ & $\begin{array}{l}\text { Applied research } \\
\text { in polytechnics }\end{array}$ & $\begin{array}{l}\text { Basic research in } \\
\text { comprehensive } \\
\text { research universi- } \\
\text { ties...applied research } \\
\text { and scholarship in } \\
\text { baccalaureate institu- } \\
\text { tions }\end{array}$ \\
\hline
\end{tabular}

(Plant, 2007). The key factor, of course, will be whether this system design and the resulting "baccalaureate" institutions can be implemented in a way to ensure horizontal differentiation rather than vertical (tiered) differentiation. Neither the student nor the system will be served if the baccalaureate credential is seen as "second tier" (relative to the existing university credential), or worse, not providing equal eligibility for graduates for further study or employment.

\section{The Baccalaureate Institution: Conditions for Success}

Success for institutions in such a "baccalaureate" category" should be defined by the extent to which they achieve differentiation and their credentials 
are recognized in an equivalent manner to those from a traditional university setting. This in turn will depend upon the adoption, in some particular balance, of institutional components usually associated with both of the traditional university or colleges sectors in order to meet the requirement of not only differentiation, but recognition and acceptance as well. These criteria/components range from the non-program substantive, but image substantive issues (e.g., the university label), to organizational issues (e.g., academic governance) and, of course, various funding issues.

However, as can be seen from all of the redesign proposals for the "baccalaureate" level institution, at the heart of the various differentiation models - and at the continuing debate about the relationship between institutional environment and degree outcomes - is the relationship between scholarship and instruction at the undergraduate level. All provincial "system redesign" proposals refer in some fashion to a limit, in either scope or intensity, on the research role of the baccalaureate-focused institution. On the other side of the issue are the existing universities and the various quality assessment bodies (both provincial and AUCC) that clearly require faculty involvement in scholarship as requirement for the approval of any institution or of individual degrees. For example, the Alberta government's framework for baccalaureate institutions says that "applied research may be conducted to foster innovation, and scholarly research activity may be conducted as a basis to enhance the instructional mandate of these institutions within degree program disciplines" (Alberta, 2007, p.8), while guidelines from the provincial quality council for Alberta state the following: "The organization has policies and procedures in place to support and facilitate engagement by academic staff in scholarship and, where appropriate, research or creative activity" (CAQC, 2006, p.5). In addition, AUCC membership requirements state that the institution

has a proven record of scholarship, academic inquiry and research, expects its academic staff to be engaged in externally peer reviewed research and to publish in externally disseminated sources, and provides appropriate time and institutional support for them to do so. Indicators of this commitment will include policies and programs pertaining to the creation of knowledge, the development of curriculum and the execution of research projects. (AUCC, 2004)

This debate about the scholarly environment would be much easier if there was some research based evidence to support the notion that there is indeed a strong link between faculty involvement in research and instructional variables such as student evaluations of instruction. The debate would also be much easier if there was a common usage of the terms "research" and "scholarship." Some reports and institutions are using the terms as if they mean different activities and others use them synonymously. Boyer's (1990) categorization of different types of scholarship may be finding an operational home in many parts of Canada. In addition, as one of the outcomes of the CMEC degree out- 
come framework, there is an expectation of a link between student involvement in faculty research activity and student knowledge and skills in research areas (CMEC, 2007). And although the debate and the research on this issue will continue, it is clear that every quality assessment process in Canada agrees that "scholarly activity" is a necessary condition for the delivery of baccalaureate degrees. Without an acceptable level of such activity in the "baccalaureate" institutions, the recognition and acceptance of their credentials is at risk.

Finally, it is worth noting that the full implementation of the new "system design" approaches in at least B.C. and Alberta will, in fact, reduce the trend to diversity in institutional type and credential that has developed over the past two decades in Canada. In B.C., challenges still remain in defining the role of some of the new universities (private as well as public). B.C. has now eliminated the confusion regarding the "university college" hybrid by making them all universities (or Polytechnic University in the case of Kwantlen). And all of the previous university colleges are now members of AUCC. In Alberta, the legislation (Bill 7) establishing a six sector post secondary system has now been passed and establishes Mount Royal and Grant MacEwan as baccalaureate institutions, SAIT and NAIT as polytechnics, and restricts degree granting to these four institutions (other than the four universities). In addition, there appears to be a trend for (a) current applied degrees to be converted to regular university degrees approved as such by the Campus Alberta Quality Council and (b) all new degrees in Alberta to be regular university level degrees similarly approved. In addition, Legislation has been introduced in Alberta that will allow both Grant MacEwan and Mount Royal to have the opportunity to put university in their institutional label. If this were to happen, together with the other changes in B.C., there will no longer be any independent, public Canadian institution offering foundational or other university-level credential that does not have the label "university" somewhere in its name. Out of the challenges of diversity may indeed come some conformity?

\section{Meeting the Challenge: Some Observations and Recommendations}

Alternate types of degrees and institutions are a growing reality in the Canadian post-secondary environment. The issue of the meaning, value and recognition of degrees will continue to be debated between the delivering institutions (universities and non-universities) and the provincial governments that approve them. Since this issue affects the futures of both institutions and individuals, it will continue to be a topic of some controversy as increasing numbers of "non-university" degree graduates hit the advanced degree and employment markets. At the very least, student consumers need to be aware of the differences in substance and recognition among the various degrees. The following are some suggestions for various stakeholders as Canada continues to address the challenge of increased differentiation of baccalaureate degrees.

To the non-university institutions: 
- University-level degrees will require selected components of universitylevel environment. Although the specific components required for this environment are still under debate, providing both academic freedom and a supportive setting for faculty teaching baccalaureate degrees to engage in a full range of scholarship will likely be considered the most critical.

- Provincial (or even United States accreditation) approval does not automatically mean that the degree would be accepted as an eligible degree for further study in Canada.

- Admission policies at Canadian universities are made at the "senate" level (and enforced by administration) and individual admission decisions are made at the department or faculty level. Policies and practices are not always consistent.

- If a degree is developed based according to CMEC guidelines and consequently has all of the components for eligibility for further study (breadth and depth, scholarship, subject affınity), then many universities will be open to bilateral agreements to provide eligibility for graduates of specific degrees from non-university institutions.

- In developing degrees that are intended to transition to further study, the curriculum should be consistent with the curriculum needs of the graduate and professional programs.

- At the same time that institutions communicate the special strengths of their degrees, they should communicate that the degree holder may not be automatically eligible for admission to graduate or professional school at Canadian universities.

- Having the label "university" does not make an institution a university or mean that its degrees will automatically be recognized as "university" degrees.

To Canadian universities:

- Recognize that the non-university degree is a growing reality. You do not have to accept these graduates, but you must develop and communicate your admission policies to these students.

- Make clear the components of university level environment required to ensure the outcomes expected from a baccalaureate. Make clear the "line in the sand."

- Recognize that undergraduate level institutions may have different, yet acceptable, approaches to faculty involvement in instruction and research.

- Recognize that there is a growing set of hybrid institutions, bringing together elements of the college environment and the university environment.

- Recognize that not all non-universities are the same.

- Recognize what special attributes non-traditional degree holders could bring to graduate and professional programs.

- Recognize the validity of provincial level qualilty assessment processes such as those done by CAQC and PEQAB. 
To provincial and national organizations:

- Ensure that ministry policies are synchronous with quality assessment policies.

- No province should act independently. There must be collaboration and cooperation across the country.

- Communicate to students the nature of the degrees you approve. Some provinces have already approved bachelor's degrees that they know will not be accepted by many universities, yet there has been no communication of this fact. Transparency of credit recognition has been a fundamental principle behind the development of course transfer guides in British Columbia, Alberta, and Saskatchewan.

- Do not approve a degree that does not meet the CMEC degree outcome expectations.

- Co-operate nationally to establish a common Canadian institutional "naming" framework or, at the very least, provide a naming rationale for the province.

- Provide institutions with the resources and support necessary to provide the outcomes of a particular degree. An applied degree seeking workplace recognition would require different resources than a foundational degree requiring academic approval.

- Provide degrees of the same name and same outcome expectations with the same level of support. That is, provide the same level of support for the same degree in a non-university environment as in a university-level environment. This would ensure that all degrees are valued the same.

- Accept that provincial level degree quality assessment (e.g., Ontario's Post Secondary Education Quality Assessment Board, Alberta's Campus Alberta Quality Council, British Columbia's Degree Quality Assessment Board) may be only the first of a two-step process to ensure that Canadian universities automatically consider degree graduates eligible. The second step would require institutional quality assessment or recognition by a national, institutional recognition process.

\section{CONCLUSIONS}

The central theme of this essay is that the concept and perceptions of the post-secondary system in Canada have not kept pace with evolutionary changes within individual institutions over the past 20 years. There are no longer clearly defined "college" and "university" sectors with clearly defined rules for governance, funding, faculty roles, or labels. The evolution of institutions across the country suggests that there is a growing spectrum of post-secondary needs and institutions. And there is now evidence that governments (and institutions) across the country are recognizing this changed post-secondary landscape. In Alberta and British Columbia, for example, the "system" is now defined more clearly than before as "multi-sector" rather than a "bi-sector." 
Although this is a welcome and perhaps overdue initiative, there is a significant caveat to the implementation of newer models of system design. These new models must be implemented in a way to ensure that there is advantage to the student in attending these new types of institutions, not disadvantage. Baccalaureate degrees are increasingly viewed as way stations on the path to further study and any baccalaureate credential that limits this educational mobility will either be ignored by the consumer, or ultimately seen as somehow fraudulent. As provinces like Alberta appear to recgonize, new institutional models must be implemented in such a way as to maximize the benefits of differentiation while ameliorating the potential disadvantages. In the case of the undergraduate institutions, although this most certainly involves different funding arrangements and different (and restrictive) mandates, it also involves support for the implementation of selected components of the traditional university environment that are universally seen as linked to university degree outcomes, and ultimately linked to the recognition and acceptance of baccalaureate institutions as university-level institutions, delivering university-level credentials. If the differentiation implementation is not done properly, it will exacerbate the degree recognition issue by giving the false impression that this "system redesign" has solved the problem. Finally, some national coordination on issues such as "system design" is long overdue.

Although there has been a start on this with the development of CMEC endorsed degree outcomes for various degree labels, the development of quality assessment councils such as the CAQC, and system redesign initiatives such as those in B.C. and Alberta, at the current time, the AUCC does provide the only national and internationally accepted standard to define "university" and it is abundantly clear that the graduates from institutions that are not members of AUCC will be disadvantaged in the pursuit of further study. AUCC will remain the arbiter of the "university" standard until such time as the various provinces coordinate their design initiatives. For example, on the issue of nomenclature, what British Columbia calls a regional university, Alberta would (at the time of the writing of this paper) call a baccalaureate and applied studies institute, Ontario calls either an Institute of Applied Learning and Technology or an undergraduate university. In addition, there is continued debate about the use of the polytechnic label in Canada. It is little wonder that, in this "tower of Babel" nomenclature environment, the world will continue to turn to AUCC as the institutional reference point for the "university-level" institution.

The reality is that provinces are not going to suddenly stop approving degrees from non-university institutions. Universities across the country are not going to stop giving preferential consideration to the graduates of AUCC-member institutions for graduate and professional schools. Provincial governments cannot simply "go around" existing university admission policies. Universities cannot simply ignore the advanced education policies of provincial governments. 
To everyone involved in this issue, colleges, universities, new college-university hybrids, governments, and assessing agencies, it is time to put aside jurisdictional squabbles and work towards a national framework that will help students, employers, and parents understand the meaning, value, and purpose of all degrees offered in Canada.

\section{NOTES}

1 See Orton (2003) for one "typology" of Canadian post-secondary institutions. The membership in some categories would be relatively fluid in Canada today. For example, other than École Polytechnique de Mont eal polytechnic in Quebec, and although there is an "unofficial" group calling themselves polytechnics, only Alberta has formally designated institutions as "polytechnics" (NAIT and SAIT).

2 "University," for the purposes of this paper, is defined by membership in the Association of Universities and Colleges of Canada. http://www.aucc. ca/about_us/membership/criteria_e.html

3 Although statistics on the number of students that pursue further study after completing a first degree are varied, an estimate would range from 40 to 50 percent depending upon program of study.

4 The colleges and universities of Ontario achieved an agreement on credit transfer between the two sectors of the provinces' post-secondary education system. The Ontario College-University Degree Completion Accord (Port Hope Accord) was signed at Queen's Park on May 6, 1999 by representatives of The Council of Ontario Universities (COU) and The Association of Colleges of Applied Arts \& Technology of Ontario (ACAAT0). In Alberta, the Alberta Council on Admissions and Transfer (ACAT) serves as a body through which stakeholders work co-operatively to ensure effective transfer of courses and programs. ACAT maintains a database of negotiated and approved transfer agreements between post secondary institutions which is accessible either by using the Online Alberta Transfer Guide or the annual printed Alberta Transfer Guide. In British Columbia, a similar organization, the British Columbia Council on Admissions and Transfer (BCCAT) serves this purpose and publishes an online and printed British Columbia Transfer Guide.

5 There can be different levels of "recognition" of degrees. The most common usage is that graduates from "recognized" degree programs are eligible for admission to a particular advanced degree, but not guaranteed that all credentials will be assessed equally in admission decisions.

6 For example, Alberta and Saskatchewan require two years of study after a first Bachelors degree to obtain a B.Ed., while Ontario requires only eight months, including ten weeks minimum of practice teaching. (This partially explains why provincial teaching certificates are not nationally recognized.) This means that the Ontario Faculties of Education have different expectations of what knowledge the student brings to the post degree B.Ed. 
than might the other provinces. Given that they have only eight months to prepare the graduates, the Ontario Faculties need to be assured that students arrive at the B.Ed. with the breadth and depth of study mentioned earlier in this discussion.

7 This specific issue has meant that some faith-based institutions in Canada have been delivering provincially approved bachelor's degrees that are not recognized by universities in Canada for either graduate school or professional school. Although most of these degrees are in either religion or theology, there are numbers of non-AUCC faith based ("independents" as they are now called in Alberta) that are branching out into more secular programming.

8 In 1970, the Carnegie Commission on Higher Education developed a classification of colleges and universities to support its program of research and policy analysis. Derived from empirical data on colleges and universities, the "Carnegie Classification" was published for use by other researchers in 1973, and subsequently updated in 1976, 1987, 1994 and 2000. A new classification scheme was announced in 2006. For over three decades, the Carnegie Classification has been the leading framework for describing institutional diversity in United States higher education.

9 In British Columbia, Kwantlen, Malaspina (now Vancouver Island University), and Fraser Valley University Colleges have now been designated "universities" as have Emily Carr and Capilano College.

\section{REFERENCES}

Alberta. (2007). Roles and mandates policy framework for Alberta's publicly funded advanced education system. Edmonton, AB: Ministry of Advanced Education and Technology.

Association of Universities and Colleges of Canada [AUCC]. (2004). Criteria to become an institutional member of AUCC. Retrieved February 26, 2009 http://www.aucc.ca/about_us/membership/criteria_e.html

Boyer, E.L. (1990). Scholarship reconsidered: Priorities of the professoriate. Princeton, NJ: Carnegie Foundation for the Advancement of Teaching.

Campus Alberta Quality Council. (2006). Institutional self-study guidelines. Available: http://www.caqc.gov.ab.ca/pdfs/CAQC_institutional_self-study_ guidelines.pdf

Canada. (2004). Building on our strengths: Higher education and research for Canada's future. Ottawa, ON: House of Commons Standing Committee on Finance.

Council for Higher Education Accreditation. (2001). The value of the degree. Retrieved November 18, 2006. http://www.chea.org/pdf/Value_of_Degree.pdf

Council of Ministers of Education, Canada [CMEC]. (2007). Ministerial statement on quality assurance of degree education in Canada. 
Dennison, J.D \& Schuetze, H.G. (2004). Extending access, choice, and the reign of the market: Higher education reforms in British Columbia, 1989-2004. The Canadian Journal of Higher Education, 34(3), 13-38.

International Association of New Generation Universities. (2007). Agreement to establish an International Association of New Generation Universities. Membership agreement signed in Dublin, Ireland, June 2007.

Jones G. A. (1996). Diversity Within a Decentralized Higher Education System: The Case of Canada. In Meek, V.L., Goedegebuure, L., Kivinen, O., \& Rinne, R. (Eds). (1996). The Mockers and mocked: Comparative perspectives on diversity, differentiation and convergence in higher education (pp. 79-93). Oxford: Pergamon.

Meek, V.L., Goedegebuure, L., Kivinen, O., \& Rinne, R. (Eds). (1996). The Mockers and mocked: Comparative perspectives on diversity, differentiation and convergence in higher education. Oxford: Pergamon.

Marshall, D. (2004a). Degree accreditation in Canada. The Canadian Journal of Higher Education, 34(2), 69-96.

Marshall, D. (2004b, August). Access to degrees in the knowledge economy. Options Politiques, pp. 76-82.

Marshall, D. (2006). Degree mobility spectrum: The tiering of Canadian degrees. Education Canada, pp. 55-57.

Marshall-Patterson Memorandum on Applied Degrees and Admission into Second-Entry, Graduate and Professional Programs. (2002, revised 2004). Ontario: Council of Ontario Universities.

Millar, E. (2007, November 29). What is a university anyways? Macleans. Retrieved December 12, 2007 from http://www.macleans.ca/education/universities/article.jsp? content=20071129_203731_5464\&page $=1$

New Brunswick. (2007). Advantage New Brunswick: A province reaches to fulfill its destiny. Fredericton, NB: Commission on Post-Secondary Education in New Brunswick.

Ontario. (1993). No dead ends: Report of the Task Force on Advanced Training. Toronto, ON: Ministry of Education and Training.

Orton, L. (2003). A new understanding of postsecondary education in Canada: A discussion paper. Ottawa, ON: Statistics Canada.

Plant, G.P. (2007). Campus 2020, Thinking ahead: The report. Victoria, BC: Government of British Columbia. Retrieved May 1, 2007 from http://www/ aved/gov/bc/ca/campus2020/campus2020-thingahead-report.pdf

Pocklington, T., \& Tupper, A. (2002). No place to learn: Why universities aren't working. Vancouver, BC: UBC Press. 
Rae, B. (2005). Ontario: A leader in learning, report and recommendations. Toronto, ON.

Randall, J. (2008). Speaking notes for lecture hosted by the Higher Education Quality Council of Ontario. Toronto, ON.

Skolnik, M.L. (2004). The community college baccalaureate in Canada: Addressing accessibility and workforce needs. In D. L. Floyd, M. L. Skolnik, \& K. P. Walker (Eds.), The community college baccalaureate: Emerging trends and policy issues (pp. 49-72). Sterling, VA: Stylus Publishing.

Skolnik, M.L. (2006). Some thoughts on the meaning of and values that influence degree recognition in Canada. College Quarterly, Volume 9 (4). Retrieved February 6, 2008 from http://www.senecac.on.ca/quarterly/2006-vol09num04-fall/skolnik.html

Smith. S.L. (1991). Commission of Inquiry on Canadian University Education. Ottawa, ON: Association of Universities and Colleges of Canada.

\section{CONTACT INFORMATION}

Dave Marshall, Ph.D.

Mount Royal College

4825 Mount Royal Gate S.W.

Calgary, Alberta T3E 6K6

dmarshall@mtroyal.ca

Dave Marshall is currently president of Mount Royal College, a primarily baccalaureate institution in Calgary, Alberta. Previously he was the founding president of Nipissing University in Ontario from 1990 to 2003. 